\title{
Vivatkurset "Førstehjelp ved selvmordsfare" er under revisjon
}

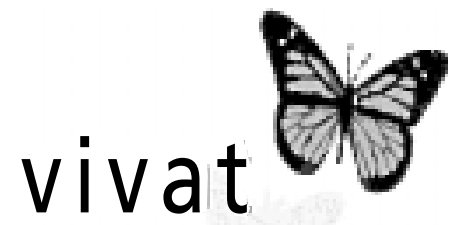

Ved Dag Willy Tallaksen

Kurset "Førstehjelp ved selumordsfare" har vaert drevet i en rekke år i Norge. Ansvarlig instans er Vivat, et landsdekkende undervisningsprosjekt som er et av oppfølgingstiltakene etter Handlingsplan mot selvmord. Etter hvert har man samlet verdifulle erfaringer og resultater fra evalueringer av kurset. Ut fra dette har man ønsket å revidere kursopplegget. Norske fagfolk har deltatt aktivt $i$ revisjonsprosessen sammen med kolleger fra flere land. Faggruppen møttes i Banff i Canada i mai $i$ år for å få presentert og diskutert resultatet av kursrevisjonen.

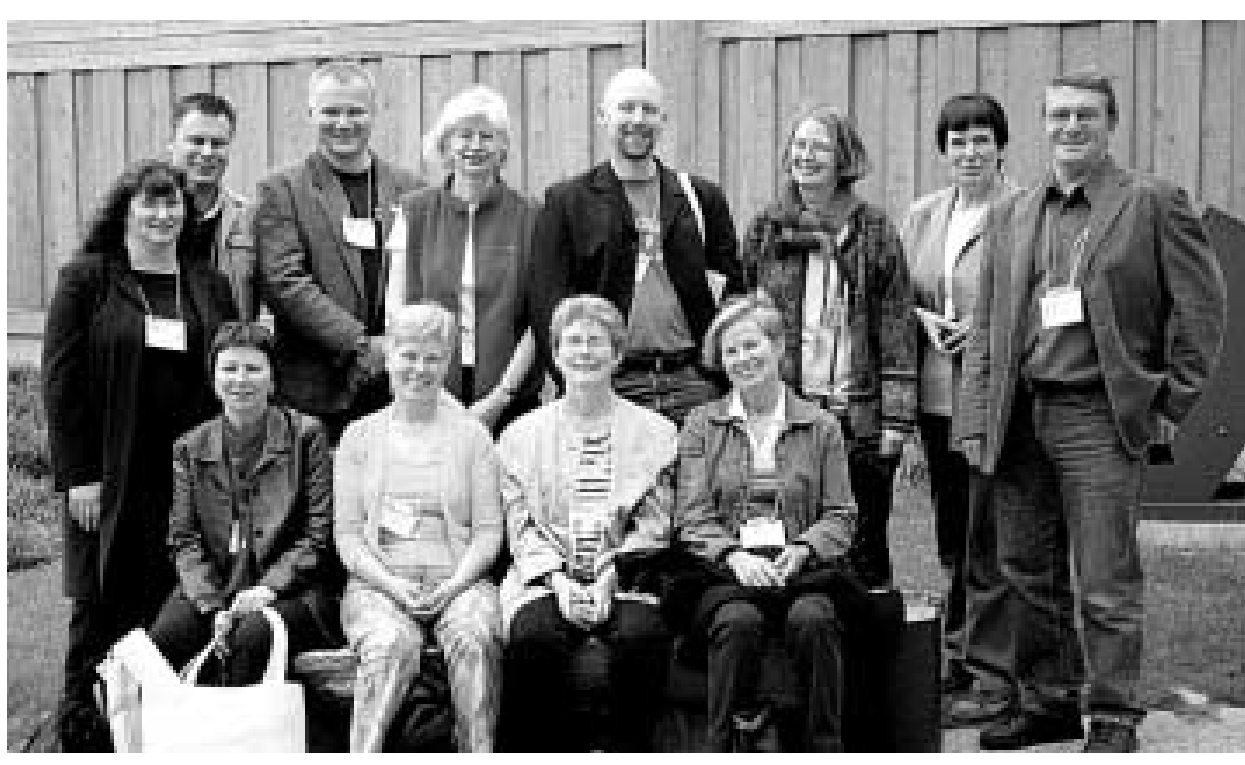

K ursledere i Vivat på konferanse i C anada (Foto: Dag W illy Tallaksen)

Den norske delegasjonen besto av våre mest erfarne kursledere og gjennom dem var samtidig alle landets regioner representert. Presentasjonen var lagt til C anada, fordi det er organisasjonen LivingW orks med base i C al gary som har stått for utviklingen av kursprogrammet siden det hele startet opp i 1980-årene. LivingW orks driver etter målsettingen "N ot for profit".

\section{Vivat og Norge er med i utviklingsarbeidet}

Førstehjel pskurset representerer en viktig aktivitet i vårt nasjonale selvmordsforebyggende arbeid. Både styret i Vivat, dagl ig ledelse og kursledere har kommet fram med et klart ønske om deltakelse og påvirkning av undervisningsoppleggets videre utvikling. I så måte er våre ønsker langt på vei imøtekommet. Kirsti Silvola, leder av Vivat, og undertegnede var invitert med i gruppen av teamledere som møttes i forkant av konferansen for å planlegge hvordan revisjonen skulle presenteres. G jennom det siste året har vi også blitt holdt orientert om hvilke endringer som har vært under plan- legging. Via e-post og personlig kontakt har det vært mulig å påvirke endringene.

G ruppen av teamledere består av representanter fra de land som i stor grad har tatt i bruk undervisningsopplegget. I praksis betyr det at representanter for $C$ anada, USA , A ustralia og N orge nå er medvirkende i den videre faglige og pedagogiske utvikling av kurset. Førstehjelpskurset er i ferd med å oppnå internasjonal spredning, og LivingW orks vil derfor legge vekt på at kurset ikke er et rent canadisk foretakende lenger.

Det spennende med konferansen var hva deltakerne skapte gjennom gruppearbeid og rollespill, i god Vivat-ånd. På konferansen var det ca. 150 deltakere fra C anada ( 9 provinser), A ustralia, USA (10 stater), Japan, R ussland (via Barentssamarbeidet) og N orge. Enkelte av deltakerne hadde holdt mange kurslederkurs, andre var relativt ferske. Felles for alle var imidlertid engasjementet for selvmordsforebygging. Vi erfarte også at mange var drevet av en betydelig grad av idealisme samtidig som de slet med elendig økonomi i sitt arbeid. Det ble tydelig for oss at på det amerikanske fastland var førstehjelpskursene en virksomhet som ikke nødvendigvismottok offentlig støtte. $M$ ange syntes nok vi var i en privilegert posisjon i og med at Vivat er tatt inn som et viktig element i den nasjonale handlingsplan mot selvmord.

\section{Endringene}

Vi var spente på hva nyhetene og forandringene besto i. Fra LivingW orks sin side ble det lagt vekt på å formidle at endringene var foretatt i overensstemmel se med erfaringer fra og evalueringer av kurset. N ye forskningsresultater er også lagt til grunn for endringene.

Det ble vist til at verdien av den risikovurderingen som hittil har vært en del av kurset, er høyst usikker og at kurset på dette punktet kan virke tilslørende. A lle personer som tilkjennegir selvmordsatferd, vil ha behov for en eller annen form for hjelp. I det reviderte kursprogrammet vil det derfor bli lagt vekt på å finne fram til den form for hjelp som er best mulig tilpasset akkurat det selvmordstruede menneske som man står overfor, uavhengig av grad av risiko. $M$ ange kursdeltakere og kursledere har gitt tilbakemel dinger som tyder på at de deler av førstehjel pskurset som er lagt opp etter tradisjonell lærer/elev-undervisningsform, har blitt oppfattet som tunge og tettpakket med faktastoff. I det reviderte kursprogrammet er det derfor gjort endringer både i innhold og undervisningsmetoder. Dialog med kursdeltakerne er vektlagt. Videre er det lagt betydelig mer vekt på å fokusere på å samtale med den selvmordsnære om temaene ambivalens og død. A samtale om døden i en førstehjelpssituasjon kan virke underlig, men døden er et sentralt tema i selvmordsatferd, og det er viktig at hjelperen gir signaler om at også døden kan snakkes om. I denne delen av samhandlingen 


\section{vivat}

ligger ofte kimen til nytt håp. Den pedagogiske utfordringen i kurset blir dermed å forberede hjel perne på å kunne samtale om døden på en meningsfull måte. For å motvirke hjel pernes opplevelse av å bli stående alene med for stort ansvar vil det nye kursprogrammet legge større vekt på betydningen og nytten av å etablere lokale nettverk av mulige hjelpeinstanser.

\section{Norske forhold}

Selv om det er foretatt mange endringer i kursopplegget, lar deg seg fortsatt lett kjenne igjen av kursledere og brukere. Rollespill og interaktive undervisningsmetoder videreføres og forsterkes, og det legges økt vekt på dialog og egenaktivitet. Både den norske gruppen og konferansedeltakerne som helhet ga tydelig uttrykk for at de foreslåtte endringer stort sett var til det bedre. I perioden fram til september d.å. vil revisjonen bli prøvd ut under en rekke kurs rundt om i verden inkludert N orge. Tilbakemeldinger fra disse kursene vil så danne grunnlaget for den endelige revisjonen som kommer i løpet av høsten.

Vivat har som mål at de viktigste dokumentene skal være oversatt i løpet av høsten. $M$ anualen som danner grunnlaget for kurslederutdanning, skal nå oversettes i sin helhet. O vergangen til den nye måten å gjennomføre kurset på, vil skje gradvis utover høsten 2003. I oktober avvikles det to kurslederkurs etter ny modell. Den endelige presentasjonen av det norske kursopplegget vil skje på en nasjonal konferanse i januar 2004.

\section{Kort kursbeskrivelse}

"Førstehjelp ved selvmordsfare" er et intensivt kurs over to dager (14 timer). Det retter seg mot alle som i sitt virke møter selvmordsnære men nesker og er et praktisk, tverrfaglig kurs hvor deltakerne lærer å oppfatte faresignaler og å gripe inn i tilfelle av akutt selvmordsfare. Kurset gir større trygghet og mer selvtillit i møte med folk som er i alvorlig tvil om de orker å leve videre.

På Vivat-kurset lærer man

- å finne ut hvordan man kan strekke ut en hjelpende hånd

- å tolke risikosignaler

- å vurdere akutt selvmordsfare

- å gjennomføre en krisesamtale

- å bruke næreliggende ressurser i krisehjelp

Kurset inneholder føl gende moduler:

- H oldninger til selvmord

- Kunnskaper om selvmord

- Risikovurdering

- Intervensjon

- Ressurser

V IVAT, U niversitetssykehuset N ord-N orge, 9291 Tromsø

TIf: 77627819

\section{www.unn.no/vivat}

Se også Kirsti Silvolas artikkel om Vivat Suicidologi 2000, nr. 3, s.15.

D ag Willy Tallaksen er høgskolelektor ved $\mathrm{H} ø$ skolen i A kershus og Vivat-koordinator i helseregion Ø st og $\varsigma \varnothing r$. samt redaksjonsmedlem i Suicidologi.

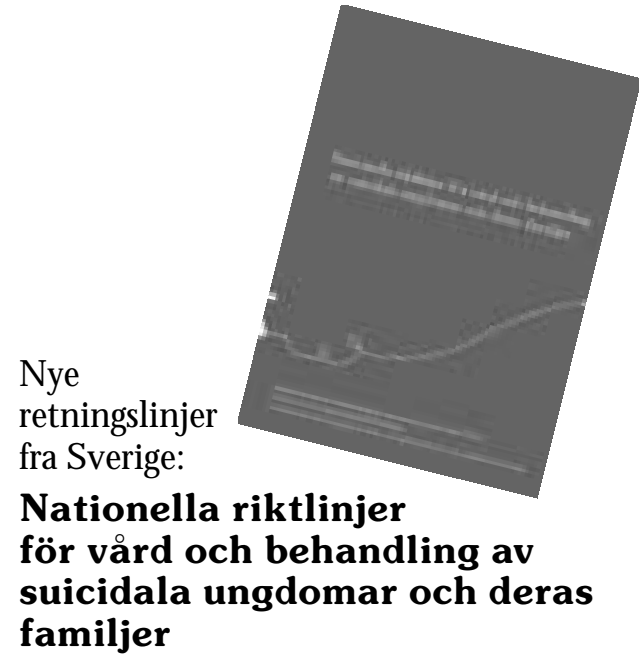

Stockholm: $N$ ationellt centrum för suicidforskning och prevention av psykisk ohälsa (N A SP), Svenska barnoch ungdomspsykiatriska föreningen, Vetenskapsrådets planeringsgrupp för barn- och ungdomspsykiatrisk och socialpediatrisk forskning, 2003. - $44 \mathrm{~s}$.

"Syftet med dessa kliniska riktlinjer är att sammanställa aktuell kunskap för att tillförsäkra självmordsnära barn och ungdomar och deras familjer så god vård som möjligt. M ålgrupperna är barn- och ungdomspsykiatrisk personal, läkare, psykologer, socionomer och vårdpersonal, samt företrädare för klinikledning och politiska beslutsfattare... [Dessa kan] också vara av värde för personal verksamma inom socialtjänst, skola och primärvård."

\section{K an lastes ned fra}

http://www.ki.se/suicid/nyhetsbrev/ RIKT LINJER 030130.pdf

\section{$\mathrm{N}$ ærmere informasjon:}

http://www.ki.se/suicid/

$H$ eftet med retningslinjene kan bestilles via e-post fra N A SP, pris kr. 50 + eksp.: Suicid.forskning@ipm.ki.se

\section{Selvmordsforskning ved Sykehuset Buskerud HF, Psykiatrisk klinikk, FoU-enheten}

Etter 5 måneder i etableringsfase er FoU enheten nå i full drift. Enheten består av fem fagstillinger og en sekretær, lokalisert ved psykiatrisk avdeling, Lier. To forskerstillinger og sekretæren er fast ansatt i enheten, mens de tre andre fagstillingene er avgitt fra hver av klinikkens tre avdelinger. Enheten skal stimulere og støtte virksomhetene i psykiatrisk klinikk til klinisk forskning, evaluering og utvikling, knyttet til barne- og ungdomspsykiatri og voksen psykiatri. Samt å bidra til at klinisk praksis skjer med størst mulig referanse til etablert kunnskap.

Følgen de er ansatt ved FoU -enheten: Professor dr. philos., spesialist i klinisk psy- kologi W encke Seltzer, Dr. med., spesialist i psykiatri Paul Møller, klinisk spesialist i psykiatrisk sykepleie, familieterapeut A nne A ndersen, overlege, spesialist i psykiatri Tone Bergerud, C and. san., psykiatrisk sykepleier $\mathrm{N}$ ina $\mathrm{H}$ elen $\mathrm{M}$ jøsund, leder.

$\mathrm{Vi}$ arbeider med et bredt spekter av problemstillinger. Blant annet har A nne A ndersen ved BU PA gjort en retrospektiv gjennomgang av utfall med hensyn til mortalitet, innleggel ser og reinnleggel ser ved selvmordsforsøk hos ungdom, en gjennomgang av tilgjengelige data fra 1983-1997 $(n=431)$. (Behandlingsmetoden er beskrevet i Fokus på familien nr. 1. 2003.) En hovedoppgave i sykepleievitenskap om selvmordsvurdering i psykiatrisk akuttpost er utført ved klinikken av $\mathrm{N}$ ina $\mathrm{H}$ elen M jøsund. Denne kvalitative studien ser på hvordan sykepleiere bidrar i en felles vurdering av selvmordsnære pasi enter ved overgang fra fotføl ging til hyppig tilsyn. En annen studie er utført ved klinikken sammen med Diakonhjemmets høyskolesenter ved høyskolelektor G ry Bruland Vråle. Studien beskriver innholdet i fotfølging ved hjelp av dybdeintervju med psykiatriske sykepleiere på ekspertnivå.

H envendelser til FoU -enheten, psykiatrisk klinikk kan skje gjennom enhetens sekretær Britt Djupvik, tel efon 32804347 eller e-mail: britt.djupvik@sb-hf.no 